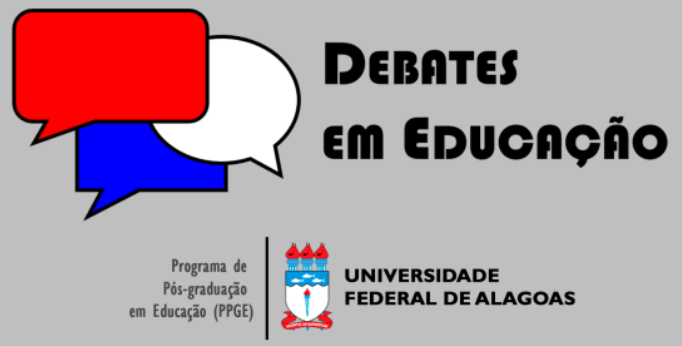

ISSN Eletrônico 2175-6600

Vol. I | No. 23 | Jan./Abr. | 2019

\section{Claudilene Silva}



Universidade da Integração Internacional da Lusofonia Afro-Brasileira (UNILAB)

claudilenems@unilab.edu.br

Eliete Santiago

9 iD

Universidade Federal de Pernambuco (UFPE) mesantiago@uol.com.br

\section{HISTÓRIA E CULTURA AFRO-BRASILEIRA NA PRÁTICA PEDAGÓGICA ESCOLAR: POSSIBILIDADES DE ORGANIZAÇÃO DO TEMPO CURRICULAR}

\section{RESUMO}

Objetivamos analisar o tempo curricular nas práticas pedagógicas de valorização da História e Cultura Afro-Brasileira em duas escolas brasileiras. Abordamos prática pedagógica como uma ação social, realizada coletiva e institucionalmente; e tempo curricular como o instrumento que organiza o trabalho pedagógico da escola. $\bigcirc$ campo foi realizado em escolas públicas em Campinas/São Paulo e Salvador/Bahia. Assumimos os Estudos Pós-Coloniais Latino Americanos como abordagem teóricometodológica em diálogo com a Afrocentricidade como posição epistemológica e adotamos a etnografia como metodologia. Na análise dos dados, adotamos a Análise de Conteúdo (AC), na perspectiva de Bardin. Os achados revelam que as diferentes formas de abordagem dos conteúdos, temas que constituem as práticas e situações didáticas que a elas dão corpo, geram uma forma outra de pensar e fazer educação.

Palavras-chave: História e cultura afro-brasileira. Prática pedagógica. Tempo curricular. Política curricular.

\section{AFRO-BRAZILIAN HISTORY AND CULTURE IN THE SCHOOL PEDAGOGICAL PRACTICE: ORGANIZATION POSSIBILITIES OF THE CURRICULAR TIME}

\begin{abstract}
We aim to analyze the curricular time in pedagogical practices valorizing Afro Brazilian History and culture in two Brazilian schools. We approach the pedagogical practice as a social action, carried out collectively and institutionally, and the curricular time as the tool that organizes the school's pedagogical work. The field was carried out in public schools in Campinas/São Paulo and in Salvador/Bahia. We embrace the Latin American Post Colonial Studies as the theorical-methodological approach in dialogue with Afrocentricity as an epistemological position, and adopt the ethonography as methodology. In regard to the data analysis, we adopted the Content Analysis (CA), from Bardin's perspective. The findings reveal that the distinct ways of approaching content, themes that constitute the practices and didactic situations that give them body, generate a different way of thinking and doing education.
\end{abstract}

Keywords: Afro-Brazilian history and culture. Pedagogical practice. Curricular time. Curricular policy.

Submetido em: 06/10/2018

Aceito em: 12/03/2019

Ahead of print em: 09/04/2019

Publicado em: 25/04/2019

do http://dx.doi.org/10.28998/2 I75-6600.2019v I In23p498-523 


\section{INTRODUÇÃO}

Atualmente, um dos maiores desafios para os profissionais da educação é dar materialidade a uma política curricular que trate pedagogicamente as diferenças de forma equitativa e respeitosa. A implementação dessa política educacional é um exercício em busca de uma educação de qualidade e em busca de uma sociedade mais democrática.

No caso da política de educação para as relações étnico-raciais, a obrigatoriedade do ensino de história e cultura afro-brasileira, africana e indígena tem mediado esse processo em construção. Sua institucionalização é uma política pública educacional de afirmação da população negra e compõe o conjunto das políticas de promoção da igualdade racial no campo da educação. Como afirma Gonçalves e Silva (20 I3, p. 2), "trata-se de uma política curricular de reconhecimento e de reparação de desigualdades". Ela integra o grupo de políticas de reconhecimento das desigualdades e discriminações raciais contra os negros no Brasil e objetiva enfrentar a injustiça nos sistemas educacionais do país. Por isso, para Gomes (2009), a política vincula-se à garantia do direito à educação e requalifica esse direito ao acrescer-Ihe o direito à diferença.

Ao considerarmos que o racismo antinegro constitui elemento estruturador das relações sociais e institucionais que foram estabelecidas no Brasil, podemos concluir que, por consequência, a política curricular do ensino de história e cultura afro-brasileira propõe modificações para a estrutura da própria sociedade brasileira. Partindo desse princípio, não será difícil compreender o nascedouro das dificuldades vivenciadas e enfrentadas no exercício de sua implementação. Como assinala Gonçalves e Silva (20 I3, p. 2),

Uma sociedade cuja herança da colonização europeia é valorizada não como um dos componentes da cultura nacional, mas como aquele em que todos deveriam privilegiadamente se pautar, os descendentes de europeus estão convencidos de que os valores, conhecimentos, tradições que herdaram de seus avós migrantes são universais.

Nesse sentido, a política põe em evidência o questionamento ao modelo único de escola e, dentro dele, à seleção e hierarquização dos conhecimentos curriculares, bem como as "dificuldades frequentes de pessoas de diferentes pertencimentos étnico-raciais, notadamente brancos e negros, indígenas e não indígenas conviverem em relações de igualdade e respeito" (GONÇALVES E SILVA, 20 I3, p. 2). Motivo pelo qual, como sugere Oliveira $(20 \mathrm{l}$ I), ela é um instrumento que pode criar as condições para a transformação das relações de subalternidade na educação brasileira, pois se propõe a ampliar o foco dos currículos, assumindo novas abordagens interpretativas sobre a identidade nacional, com alguns pressupostos não-eurocêntricos. 
Por outro lado, como temos observado, a forma como a política vem sendo implementada aponta que a construção e o enraizamento de práticas pedagógicas voltadas para essa temática constituem um processo longo, que apresenta limites e lida com contradições. Os limites experienciados na implementação da política educacional revelam dificuldades que emergem na construção e vivência das práticas pedagógicas no cotidiano da instituição escolar. Por sua vez, se por um lado, como bem lembram Oliveira e Lins (20।3), os avanços conquistados a partir da produção acadêmica que existe nesse campo concentram-se em elementos históricos, jurídicos e ideológicos, por outro, as questões propriamente pedagógicas e teóricas da formação docente, bem como das vivências e práticas escolares, ainda estão em processo de produção.

Buscando contribuir com esse processo, o objetivo deste artigo é analisar o tempo curricular empregado nas práticas pedagógicas de valorização da história e cultura afro-brasileira e africana em duas escolas brasileiras, refletindo sobre suas possibilidades e escolhas pedagógicas.

Para as escolhas teórico-metodológicas, orientamo-nos por duas ideias: que o racismo antinegro, como ideologia e como prática de dominação social, é elemento estruturador das relações sociais, étnicoraciais e pedagógicas vivenciadas na sociedade brasileira (CUNHA JR., 2013) e que raça, como discute Munanga (2000), é uma construção social forjada nas tensas relações de dominação e poder entre brancos e negros, europeus e não-europeus.

Desse modo, biológica e cientificamente, as raças não existem (MUNANGA, 2000). A biologia cumpriu o papel de fornecer os elementos para que a ideia de raça fosse transformada no racismo científico do século XIX(SANTOS, 2002). Assim, como realidade biológica, a única raça que existe é a raça humana, mas, como realidade social e política, a ideia de raça continua operando como construção social de dominação e de exclusão (MUNANGA, 2000).

Nesse sentido, no Brasil, tanto o movimento negro como os estudiosos e estudiosas do campo das relações raciais (Antônio Sergio Guimarães, Sérgio Costa, Lilia Schwarcz, Henrique Cunha Junior, Nilma Gomes, entre outros e outras) têm discutido e utilizado o conceito de raça como categoria sociológica. Consideram "que se as raças não existem num sentido estrito e realista de ciência, ou seja, se não são um fato do mundo físico, elas existem, contudo, de modo pleno, no mundo social" (GUIMARÃES, 1999 p. 67). Dessa forma,

não o fazem alicerçados na ideia de raças superiores e inferiores, como originalmente era usada no século XIX. Pelo contrário, usam-no com uma nova interpretação, que se baseia na dimensão social e política do referido termo. E, ainda, usam-no porque a discriminação racial e o racismo existentes na sociedade brasileira se dão não apenas devido aos aspectos culturais dos representantes de diversos grupos étnico-raciais, mas também devido à relação que se faz na nossa sociedade entre esses e os aspectos físicos observáveis na estética corporal dos pertencentes às mesmas" (GOMES, 20।2a, p. 45) . 
Ou seja, utilizada inicialmente para justificar, cientificamente, a supremacia branca, a categoria raça foi assumida pelo movimento negro como instrumento estratégico na luta contra o racismo e as desigualdades raciais!.

A partir dessa perspectiva, aproximamo-nos dos Estudos Pós-Coloniais Latino Americanos como abordagem teórico-metodológica em diálogo com a Afrocentricidade como posição epistemológica, compreendendo-os como possibilidades de produção de um conhecimento de ruptura com a hegemonia do pensamento eurocêntrico.

Os Estudos Pós-Coloniais Latino-americanos, abordagem profundamente enraizada na dimensão do locus de enunciação do sujeito que fala, possuem como questão central o desvelamento da articulação entre modernidade/colonialidade e suas implicações na organização da dominação eurocentrada. Para essa abordagem, raça é uma construção mental inventada para hierarquizar as populações mundiais, segundo a gradação da sua cor e "naturalizar" o padrão mundial do poder capitalista eurocentrado e colonial/moderno (QUIJANO, 2005).

A Afrocentricidade é "um tipo de pensamento, prática e perspectiva que percebe os africanos como sujeitos e agentes de fenômenos atuando sobre sua própria imagem cultural e de acordo com seus próprios interesses humanos" (ASANTE, 2009, p. 93). Para esse pensamento, longe de ser um termo essencialista, o "africano" é um construto do conhecimento: ser africano é ser uma pessoa que participou dos 500 anos de resistência à dominação europeia (ASANTE, 2009), e, como essa atuação vem acontecendo na margem da experiência europeia, a Afrocentricidade trata-se do movimento de corrigir esse deslocamento e posicionar o africano no centro de sua história.

Adotamos a etnografia como possibilidade metodológica adequada para o trato das práticas pedagógicas de valorização da identidade, da memória e da cultura negras por sua capacidade de amplificar as vozes dos sujeitos outrora silenciados. Abordamos a categoria prática pedagógica a partir da conceituação de Souza (2009): uma ação social coletiva, realizada institucionalmente, com intencionalidades explícitas e assumidas pelo conjunto da comunidade escolar. E, para analisar as práticas pedagógicas sobre a temática, apoiamo-nos no pensamento negro em educação e no pensamento do educador Paulo Freire, como pilares orientadores do olhar pedagógico.

trabalho de campo foi realizado em duas escolas públicas, situadas nas regiões Sudeste e Nordeste do país, indicadas como instituições que possuem práticas pedagógicas de enraizamento intenso no trabalho com história e cultura afro-brasileira e africana. Na Região Sudeste, o estudo foi realizado na Escola Municipal de Ensino Fundamental Africanidades², que está localizada na cidade de Campinas, estado

\footnotetext{
I Neste trabalho utilizamos o termo "raça" para identificações baseadas em características físicas e o termo etnia para identificações baseadas em características culturais.

2 Nome fictício.
} 
de São Paulo, e foi indicada pela pesquisa Práticas Pedagógicas de Trabalho com Relações Étnico-Raciais na Escola na Perspectiva da Lei no $10.639 / 03$ (GOMES, 2012b). Na Região Nordeste, o trabalho aconteceu na Escola Municipal de Ensino Fundamental Baobáa ${ }^{3}$ localizada na periferia da cidade do Salvador, estado da Bahia, sendo indicada pela coordenação do Programa de Educação e Profissionalização para a Igualdade Racial e de Gênero (CEAFRO).

No tratamento, produção e análise dos dados, adotamos a Análise de Conteúdo (AC), na perspectiva de Laurence Bardin (20II). Por meio da análise temática, buscamos evidenciar os sentidos dos núcleos de sentido e significação das informações. Na leitura do conjunto de documentos com o qual trabalhamos, algumas categorias ganharam destaque na análise dos dados: o ritual pedagógico, o itinerário pedagógico e o tempo curricular. Juntos, esses elementos compõem o que podemos chamar de ciclo de construção e vivência das práticas pedagógicas no espaço escolar.

Sem perder de vista que a vivência das práticas pedagógicas de valorização da história e cultura afro-brasileira e africana se dá de forma articulada entre esses elementos, neste artigo, focalizamos a discussão das possibilidades de organização do tempo curricular na construção e vivência dessas práticas.

O texto está organizado em duas partes: na primeira, apresentamos a concepção de currículo e de prática pedagógica que orienta nosso trabalho. Na segunda, analisamos como o tempo curricular é utilizado nas práticas pedagógicas de valorização da história e cultura afro-brasileira e africana no contexto das escolas que participaram da pesquisa.

\section{CURRÍCULO, PRÁTICA PEDAGÓGICA E TEMPO CURRICULAR}

Os processos educativos estão intrinsecamente relacionados aos contextos sociais nos quais se desenvolvem. Estudos realizados por Gatti, Barreto e André (20I I) sobre as políticas docentes no Brasil apontam que as novas realidades contemporâneas, preocupadas com a educação como um direito humano e entendendo o direito à educação como o direto à diferença (inclusive curricular), solicitam um novo perfil docente e incidem diretamente nos currículos que circulam tanto nas escolas como nas instituições formadoras.

Gatti et al. (20l I) afirmam que os modos de gestão do currículo constituem uma das maneiras por meio das quais a política docente se efetiva, se materializa, ganha vida. As autoras apontam indícios de que o currículo é um território em disputa social, e que essa disputa pode ser percebida, inclusive, a partir da concepção de currículo defendida por cada uma das partes interessadas. Nos referenciais nacionais, embora se busque responder à demanda social de inserção de questões como pluralidade cultural, gênero

\footnotetext{
${ }^{3}$ Nome fictício.
} 
e sexualidade e meio ambiente, entre outros temas atuais, o currículo ainda é estruturado de forma dicotômica e hierárquica. De um lado estão as áreas do conhecimento e, de outro, os temas considerados transversais, como ainda é o caso do ensino de história e cultura afro-brasileira e africana.

Assim, partimos do pressuposto de que os rituais que predominam na instituiç̧ão escolar estão alicerçados no racismo e atuam na manutenção da discriminação e do preconceito étnico-racial: os currículos estão estruturados de forma a ignorar a existência das pessoas que fogem ao padrão do ser humano universal: homem, branco, rico e heterossexual; os livros infantis, por meio de seus contos de fada, ignoram a existência das pessoas negras ou as apresentam de forma depreciativa; os brinquedos disponibilizados, especialmente as bonecas, oferecem apenas a representação da população que possui características brancas; nos cartazes escolares, a população não branca, quando não é excluída, é representada de forma estereotipada; e a história da população negra ainda é abordada a partir da perspectiva da escravidão sofrida e não da resistência à escravidão, empreendida pelos descendentes de africanos no Brasil. Nas palavras de Gonçalves (1985), são rituais pedagógicos a favor da discriminação racial.

De acordo com Cury (1992, p. I 18), "a concepção de mundo não se reproduz apenas pela conceituação. Ela se expressa nas práticas escolares, desde as mais simples as mais sofisticadas". Para Gonçalves (1985), a história e a cultura afro-brasileira, entendidas como patrimônio histórico-cultural dos grupos étnico-raciais negros, podem, por meio do seu disciplinamento, transformar-se em um outro ritual pedagógico. Para ele, a fala cumpre um importante papel nessa ritualização. A constituição de um repertório sobre a temática é de extrema importância. Ouvir outras histórias, possuir outras referências é imprescindível para construir outros rituais.

Compreendemos, portanto, que, como parte de uma prática social mais ampla, a prática pedagógica orienta-se, estrutura-se e responde a objetivos e finalidades de cada tempo e contexto social. De acordo com Freire (2010, p. 98), "como experiência especificamente humana, a educação é uma forma de intervenção no mundo". Sendo assim, a ação pedagógica se materializa pela sua intencionalidade. Ou seja, o caráter pedagógico da prática educativa se verifica como "ação planejada e intencionalmente realizada por seus sujeitos" (SOUZA, 2009, p. 34). No caso da escola, ela é mediada pelo currículo escolar, o qual compreendemos de forma ampla, como afirma Santiago (2006, p. 74): a "materialização de um projeto que traça um tipo de educação e uma concepção de sujeito, que ganha significado e traça identidades através dos processos de ensino e de aprendizagem”. Todavia, para Gonçalves ( 1985, p. 3 I 5), "ao ser incorporada pela escola, uma ação por mais ingênua e despretensiosa que possa parecer, tem força pedagógica."

Consideramos, ainda, que, no âmbito da escolarização, os processos de ensino e aprendizagem não se dão apenas na sala de aula, mas em todos os espaços da escola por meio das relações estabelecidas 
entre todos os atores que conformam a comunidade escolar. Santiago (2006, p. 74) ressalta que a abordagem do currículo como prática pedagógica centra seu interesse nas "práticas administrativas e pedagógicas que ocorrem no âmbito escolar e não escolar, além daquelas oriundas da relação docentediscente". Nessa perspectiva, chama-nos especial atenção o fato de que, ao fazermos referência ao caráter pedagógico da instituição escolar ou mesmo da educação, a alusão às ações desenvolvidas pelas professoras e professores é quase sempre o ponto de convergência.

Ainda que consideremos a relevância da atuação docente como mediadora dos processos de escolarização, atribuir-lhes demasiada centralidade nesses processos é isentar os demais atores da instituição escolar (discentes, gestores, funcionários) de suas responsabilidades na relação dialógica que se faz necessária a qualquer prática educativa, se consideramos a perspectiva freireana de educação.

Para Souza (2009), nas últimas décadas, os pesquisadores em educação usaram a expressão prática docente como sinônima de prática pedagógica. Entretanto, de acordo com esse autor, embora a prática pedagógica legitime o exercício da profissão docente, tal prática está situada no interior de processos complexos para os quais concorrem inúmeras variáveis e diferentes práticas que conformam a formação docente. Ou seja, de acordo com o autor, a prática docente é apenas uma das dimensões da prática pedagógica interconectada com a prática gestora, a prática discente e a prática gnosiológica e/ou epistemológica, o que torna inadequado reduzir a prática pedagógica à prática docente.

Na perspectiva de Souza (2009), a prática pedagógica é uma práxis, ou seja, uma ação coletiva específica, dentro do fenômeno social mais amplo, que é a educação, organizada com finalidade e objetivos explícitos a serem desenvolvidos em conjunto pela instituição.

Na produção acadêmica recente ${ }^{4}$, não encontramos referência ao conceito de prática pedagógica em seu conjunto. Ela aparece com frequência como um de seus elementos constitutivos: a política curricular, a avaliação, a atividade do docente, o planejamento etc. Em boa parte dos trabalhos, é abordada como contexto de produção da política educacional ou como campo empírico de investigação. Todavia, a produção oferece indícios do que constitui o caráter distintivo, a totalidade e a particularidade de uma prática pedagógica.

A prática pedagógica acontece no cotidiano das relações que são desenvolvidas numa instituição educativa e se estrutura no desenvolvimento das ações cotidianas dos sujeitos. É uma prática intencionalmente organizada para alcançar objetivos específicos; dinâmica, manifesta-se como gesto, atitude e comportamento reflexivo e criativo. Embora a prática aconteça a partir da ação do educador, ela não é uma prática do educador, mas da instituição educativa, configurando-a como uma prática coletiva.

\footnotetext{
${ }^{4}$ Realizamos um estudo sobre os usos e sentidos da categoria prática pedagógica em seis grupos de trabalho da ANPEd, de 2003 a 20 I3: GT 03 - Movimentos Sociais, Sujeitos e Processos Educativos; GT 04 - Didática; GT 06 - Educação Popular; GT 08 - Formação de Professores; GT 12 - Currículo e GT 21 - Educação e Relações Étnico-Raciais.
} 
Os processos de organização e de atuação (o tempo, o espaço e a rotina) constituem parte estrutural do desenho e da ação da prática pedagógica. É, portanto, uma prática formativa composta por muitas outras práticas: práticas organizativas, práticas discursivas, práticas de ensino, práticas de aprendizagem, práticas avaliativas, práticas relacionais etc.

Ela se revela por meio dos diversos rituais, construídos a partir de uma concepção de sociedade, de educação, de conhecimento, de ensino e de aprendizagem para vivenciar as diversas práticas que a instituem. Constituem seus elementos predominantes: intencionalidade; institucionalidade; estruturação a partir de uma concepção de educação e de conhecimento; articulação e cooperação entre os sujeitos que a vivenciam; e formas de organização coletiva do trabalho dos diversos sujeitos que compõem a instituição educativa.

O conjunto dos trabalhos aponta quatro possíveis sentidos para entender o termo prática pedagógica no cotidiano da instituição escolar: I) Ação docente - a atuação desenvolvida pelas professoras e pelos professores no exercício de sua profissão; 2) Ação formativa - a metodologia de trabalho de uma pessoa ou instituição para desencadear um ciclo de ensino-aprendizagem: as concepções que fundamentam a ação, as estratégias de ação utilizadas, a sequência didática de operacionalização; 3) Ação discursiva - a prática discursiva realizada durante a ação formativa, mas também o paradigma discursivo que orienta a ação. 4) Espaço e forma de materialização do currículo como construção do conhecimento - a atividade intencional e estratégica de construção do processo de ensino-aprendizagem. É este último sentido de prática pedagógica que gostaríamos de aprofundar ao discutir o tempo curricular empregado nas práticas pedagógicas de valorização da história e cultura afro-brasileira e africana.

$\mathrm{Na}$ análise do ciclo de construção e vivência das práticas pedagógicas no espaço escolar, o ritual pedagógico foi compreendido como as situações, os conteúdos e as relações que são vivenciadas, articuladamente, ao longo da construção do conjunto de práticas pedagógicas de uma instituição. A projeção desse caminho de construção, Maria do Socorro Silva (2009) denominou itinerário pedagógico. Ou seja, itinerário pedagógico é a escolha do caminho a trilhar por cada instituição na construção do conhecimento. De acordo com a autora, é esse itinerário que caracteriza a prática pedagógica de cada instituição, conferindo-lhe especificidade, porque atua como instrumento orientador da dinâmica e da organização do trabalho pedagógico. Por sua vez, é no e com o tempo curricular que a instituição organiza o trabalho pedagógico. Santiago (1990) identificou o tempo curricular como o instrumento básico da organização e do funcionamento da escola por meio do qual se dá o ciclo de construção do conhecimento escolar e o processo de produção e vivência do projeto político pedagógico da escola. A "situação real, onde e quando se concretizam as relações pedagógicas" (SANTIAGO, 1990, p. 50).

Desse modo, o tempo curricular é o instrumento que dá andamento, pulsação e conteúdo às atividades que serão realizadas no espaço escolar. É a forma de arrumação que cada instituição estabelece 
para viver o currículo. Portanto traduz o jeito de organizar o ritual pedagógico e se constitui no eixo que garante o rumo da prática definido no itinerário pedagógico.

Para dar conta dos objetivos propostos, direcionamos o olhar para as práticas pedagógicas enraizadas. Noção por nós elaborada ao longo do estudo para designar aquelas práticas que possuem enraizamento no trabalho pedagógico da escola; que criaram raízes no chão da instituição escolar; que não estão apenas na superfície do trabalho pedagógico. Elas fazem parte da sustentação da escola, estão no alicerce, no fundamento do trabalho pedagógico. E, em função desse aprofundamento, da continuidade e recorrência, elas se estabeleceram na escola, fixaram-se como rituais pedagógicos. Ou, em outras palavras, práticas que não sendo repetidas mecanicamente, resultam de uma reflexão do grupo; possuem fundamento, uma finalidade construída, explicada e argumentada pelas pessoas que protagonizam o trabalho pedagógico na escola. Suas características são a repetição crítica, a continuidade e a consistência.

Dentre as muitas práticas enraizadas existentes no espaço escolar, recortamos as práticas de valorização da história e cultura afro-brasileira e africana. Portanto apuramos nosso olhar para as práticas pedagógicas enraizadas que possuíam como conteúdo pedagógico "a História da África e dos Africanos, a luta dos negros no Brasil, a cultura negra brasileira e o negro na formação da sociedade nacional" (Lei nº 10.639/03), como está explícito no texto que alterou a Lei no 9394/96 de Diretrizes e Bases da Educação Nacional.

\section{TEMPO CURRICULAR: A ORGANIZAÇÃO DOS CONTEÚdOS PEDAGÓGICOS EM HISTÓRIA E CULTURA AFRO-BRASILEIRA E AFRICANA NO ESPAÇO ESCOLAR}

A concepção de currículo e prática pedagógica com as quais trabalhamos nos possibilita olhar para os conteúdos pedagógicos sem nos restringirmos à sua dimensão programática. Desse modo, ao analisarmos o tempo curricular - a organização da vivência dos conteúdos pedagógicos no espaço escolar, focaremos três aspectos: a forma de abordagem do conteúdo, os temas que constituem as práticas e as situações didáticas que a elas dão corpo.

Ao analisarmos o conjunto das práticas pedagógicas desenvolvidas e vivenciadas nas escolas campo de pesquisa, percebemos que a forma de abordagem da temática história e cultura afro-brasileira e africana pode se dar de forma específica, em momentos criados especialmente para tratar o tema, como no caso das oficinas temáticas e da mostra anual da Escola Africanidades; ou de forma integrada aos outros conteúdos disciplinares, como acontece na Escola Baobá. Em ambos os casos, a abordagem é sempre 
intencional e coletivamente planejada, conforme o sentido de prática pedagógica que encontramos em Souza (2009), referência que adotamos neste trabalho.

A oficina temática mídia e racismo pode ser tomada como exemplo da abordagem de forma específica. A atividade foi elaborada e oferecida pelo professor de história durante a semana de oficinas temáticas da Escola Africanidades. A situação didática problematizadora utilizada foi a seguinte:

o professor circulou entre os estudantes materiais de propaganda que ele mesmo recolheu nos sinais de trânsito da cidade durante todo o mês de outubro/20 4 (propaganda de imóveis, carros, lojas, mês das crianças entre outras) e pediu para que eles analisem. Um primeiro grupo logo percebeu que em todos os materiais só havia e representação de pessoas brancas. Em outro grupo foi necessária à condução do professor no processo de percepção dessa informação. Após esse momento outros materiais foram mostrados (na TV, nas revistas, nas redes sociais etc.); discutia-se a questão - Porque o grupo achava que não havia negros nos materiais, se metade da população brasileira é negra? E o grupo era convidado a produzir cartazes com anúncios publicitários com a participação de pessoas negras (Oficina mídia e racismo registrada no diário de campo em 03// I/20|4).

A percepção das/os estudantes a respeito de que a ausência de representação da população negra na mídia brasileira possui uma conotação racista foi sendo construída a partir da leitura crítica e por meio da reflexão coletiva do grupo, com o auxílio do professor, ao longo da atividade.

As dificuldades encontradas para realizar a tarefa solicitada também podem ser consideradas nesse processo de percepção, pois a procura, sem sucesso por imagens de pessoas negras nas revistas torna concreta a ausência dessa população na mídia, como se pode notar na situação a seguir:

Durante a confecção dos cartazes um dos garotos, que estava produzindo um anúncio publicitário de celulares, perguntou ao professor se poderia colocar a fotografia de uma criança. O professor questionou: - Mas numa propaganda de celular? Ao que o garoto respondeu: - Mas, professor, está muito difícil encontrar gente negra nessas revistas! (Oficina mídia e racismo registrada no diário de campo em 03/I I/20|4).

Cabe destacar que havia cerca de cinquenta revistas na sala e o professor achou interessante o comentário do estudante para explorar o tema que estava sendo discutido.

A abordagem de forma integrada aos conteúdos disciplinares, sempre que possível, acontece de maneira interdisciplinar, expressa uma relação dialógica e oferece uma visão dos próprios afro-brasileiros sobre si e sobre os acontecimentos. Certo dia, uma das professoras da Escola Baobá, ao iniciar uma aula de história cujo tema era agricultura, explicou à sua turma do $5^{\circ}$ ano: "hoje vamos estudar história no livro de ciências, porque eu encontrei um texto interessante sobre solo no livro de ciências e em agricultura a gente também estuda solo" ${ }^{5}$. A proposta de trabalho da escola nos permite afirmar que o trabalho interdisciplinar, na verdade, não é apenas porque a professora encontrou o texto no livro de ciências. Ao assumir a cultura afro-brasileira como núcleo organizador de sua prática pedagógica, a Escola Baobá assumiu também a cosmovisão africana que orienta essa cultura. $\bigcirc$ princípio da integração presente na

${ }^{5}$ Situação em sala de aula registrada no diário de campo em 10/06/20। 5. 
forma cultural africana recriada no Brasil (OLIVEIRA, 20I2) possibilita que as situações didáticas sejam criadas de forma interdisciplinar e ou transdisciplinar. Por outro lado, a situação didática vivenciada apresenta traços da relação dialógica educador/educando freireana, como é possível identificar no registro a seguir:

Para iniciar o diálogo, a professora perguntou à turma quem conhecia alguma coisa sobre a história do Brasil. Um dos estudantes explicou sobre a chegada dos portugueses e que não foi descobrimento. Foi uma invasão, porque outras pessoas já habitavam o território. Depois da invasão os africanos foram trazidos para trabalhar nas lavouras. A professora aproveitou a fala do garoto para introduzir a questão da agricultura. Em sua fala ela explicou que os povos africanos foram escravizados por conta do conhecimento que eles possuíam sobre a agricultura. E ainda assim, durante muito tempo foi dito que os povos africanos não sabiam de nada. Mas, esse povo sabia muitas coisas. Então a professora começou a explorar o conceito de agricultura com as crianças (Situação em sala de aula registrada no diário de campo em 10/06/20 I5).

A professora cria as condições para a problematização da situação e a reflexão crítica para desconstruir estereótipos que terminam por justificar a escravidão negra e a dominação colonialista sobre os povos africanos.

Os traços de uma prática dialógica permeada pela visão dos próprios afro-brasileiros sobre os acontecimentos, suas vidas e suas histórias (como propõe a abordagem afrocentrada) aparecem em vários momentos e nas diversas situações didáticas. A forma mais recorrente, entretanto, é aquela que trata dos acontecimentos históricos e busca desconstruir a visão eurocêntrica de uma história única sobre as várias populações humanas, especialmente, sobre os africanos e afro-brasileiros. Quer seja na prática docente ou em outros tempos/espaços da dinâmica da escola, as situações são abordadas a partir das datas comemorativas ou dos temas acolhidos em cada trimestre para a discussão. Mas, em todos os casos, procuram construir uma reflexão sobre a realidade dos estudantes e mobilizá-los para sua superação, com as possibilidades de que dispõem. A situação a seguir, vivenciada em oficina de contra turno do período integral por uma turma do $5^{\circ}$ ano, ilustra a articulação referida:

A professora inicia a conversa perguntando: - $\bigcirc 02$ de julho é feriado de que?

As crianças respondem: - Independência da Bahia.

Professora: - $\bigcirc$ que é ser independente?

Crianças: - Se governar; - Não depender de ninguém; - Ser dono de seu nariz.

Professora: - E a Bahia era dona de seu nariz?

Um garoto responde: - Não! Ela obedecia a Portugal.

Outro estudante pergunta: - Se o Brasil já era independente e a Bahia pertence ao Brasil, como a Bahia ainda não era independente?

A professora explica que o território era muito vasto e que os portugueses resistiram escondidos na Bahia e afirma: - Então o povo baiano lutou muito por sua libertação. Inclusive com a participação de algumas mulheres, com destaque para D. Maria Felipa, Maria Quitéria e a freira Joana Angélica.

Na continuação da explicação a professora afirma que:

- A visão europeia, que é a visão dos brancos que exclui o povo, os negros, os pobres, os índios etc. da participação na história, não fala da importância das mulheres, só falam do general.

E continuou falando da visão europeia, com o exemplo de que:

- Antigamente quando nós estudávamos sobre o Egito, era apresentado como se o Egito não fizesse parte da África. 
Um estudante afirma: - Nos desenhos animados que fala sobre o Egito, os bonecos são todos brancos!

A professora lembra que isso é para diminuir a luta e a imagem da África.

Em seguida prossegue contando um pouco do episódio do 02 de julho para os estudantes.

Afirma ainda que: - Mesmo depois da independência, a situação dos baianos não melhorou. Por isso é importante que vocês estudem, lutem por suas vidas, para terem uma vida melhor.

(Situação de oficina em sala se aula registrada no diário de campo em 06/07/20 I5)

É importante destacar que há aproximações epistemológicas na perspectiva dos Estudos PósColoniais Latino-Americanos, assim como da Afrocentricidade. A reflexão evidencia um discurso contrahegemônico, que mostra a participação histórica de grupos subalternizados pelo colonialismo/colonialidade, ao mesmo tempo em que apresenta o contexto histórico da perspectiva construída pela população negra.

planejamento presente em ambas as abordagens ganha centralidade, porque representa um avanço no processo de enraizamento das práticas pedagógicas de valorização da população negra no espaço escolar. De acordo com as Diretrizes Curriculares Nacionais para a Educação das Relações ÉtnicoRaciais e para o Ensino de História e Cultura Afro-Brasileira e Africana, para obter êxito em sua intervenção, "a escola e seus professores não podem improvisar" (BRASIL, 2004, p. I 5), diante da magnitude do desafio que constitui "desfazer mentalidade racista e discriminadora secular, superando o etnocentrismo europeu, reestruturando relações étnico-raciais e sociais, desalienando processos pedagógicos" (BRASIL, 2004, p. 15).

Em pesquisa anterior, quando o centro da análise focou a prática docente sobre relações étnicoraciais no espaço escolar, percebemos que a abordagem da temática se dava de forma espontânea e que o tratamento pedagógico acontecia como "algo a parte dos conteúdos curriculares, como se preconceito, discriminação e relações étnico-raciais não compusessem o repertório dos conhecimentos que são transformados em conteúdos de ensino" (SILVA, 20 I3, p. I65). O espontaneísmo do trabalho, ao colocar a temática à margem dos conteúdos de ensino, levava a desconsiderá-la como conteúdo curricular.

Souza (2009) afirma que os conteúdos pedagógicos se subdividem em conteúdos educacionais, instrumentais e operativos. Os conteúdos educacionais são constituídos pela compreensão, interpretação e explicação do contexto histórico cultural em que vivemos. Os conteúdos instrumentais são aqueles que dizem respeito à aprendizagem das linguagens verbais (escritas e orais), das matemáticas e das linguagens artísticas. E os conteúdos operativos são compostos pelo desenvolvimento da capacidade de projetar intervenções sociais em diferentes âmbitos. De acordo com essa categorização, a temática em questão compõe os conteúdos educativos e vários de seus temas podem ser trabalhados de forma articulada aos conteúdos instrumentais. 


\section{I Temas das práticas pedagógicas em história e cultura afro-brasileira e africana}

O mapeamento dos temas que constituem as práticas pedagógicas foi elaborado a partir de fontes diversificadas. Elencamos os conteúdos mais recorrentes na abordagem da temática, evidenciados nas situações em sala de aula, nas atitudes da comunidade escolar, nas atividades propostas pela escola e também no material produzido pelos estudantes nas várias atividades a eles direcionadas. A abordagem da história e cultura afro-brasileira e africana no espaço escolar, que dá vida às práticas enraizadas, acontece por meio de quatro blocos temáticos.

No primeiro, a ênfase recai sobre a tensão entre a supremacia branca e a resistência negra, explorada a partir da construção do lugar de subalternidade dos povos negros e das lutas empreendidas pela população negra para superação dos estigmas contra ela construídos. No segundo, destacam-se aspectos relativos aos processos de construção e percepção da identidade negra e da autoestima da população negra, enfocando a história e a estética de pessoas negras. $\bigcirc$ terceiro bloco temático refere-se aos processos políticos que construíram o discurso de democracia racial brasileiro e as formas encontradas pela população negra para desconstruí-lo, denunciar o racismo e reivindicar ações afirmativas de reconhecimento e reparação para a população negra no Brasil. Por fim, no quarto bloco, ganham relevo aspectos relativos à África e às africanidades no Brasil, com destaque para a compreensão da África como berço da humanidade e dos valores civilizatórios africanos recriados em território brasileiro, especialmente, por meio das religiões de matriz africana, conforme observamos no quadro a seguir:

Quadro I - Temas que constituem as práticas pedagógicas de valorização da história e cultura afro-brasileira e africana

\begin{tabular}{|c|c|}
\hline TEMAS & CONTEÚDOS \\
\hline \multirow{6}{*}{$\begin{array}{l}\text { Supremacia branca } \\
\text { e } \\
\text { Resistência negra }\end{array}$} & $\begin{array}{l}\text { A visão europeia sobre a história da humanidade } \\
\text { - A negação da população negra, de seus conhecimentos e forma de pensar. } \\
\text { - A construção do lugar de subalternidade da África. }\end{array}$ \\
\hline & A história dos escravos e dos escravizados. \\
\hline & A história do 13 de maio e a abolição. \\
\hline & A participação da população negra nos episódios históricos (locais). \\
\hline & $\begin{array}{l}\text { As possibilidades de crescimento pessoal e coletivo da população negra, apesar das } \\
\text { adversidades. }\end{array}$ \\
\hline & $\begin{array}{l}\text { Personalidades de referência para a luta negra: } \\
\text { Martin Luther King; Maria Carolina de Jesus; Zumbi dos Palmares; } \\
\text { Rainha Nzinga. }\end{array}$ \\
\hline \multirow{5}{*}{$\begin{array}{l}\text { Identidade negra, } \\
\text { autoestima e autoconceito }\end{array}$} & $\begin{array}{l}\text { Identidade: autorretrato, autoestima. } \\
\text { Importância da família. }\end{array}$ \\
\hline & Igualdade e diferença. \\
\hline & Cuidados pessoais e com a autoestima. \\
\hline & Estética negra: cabelo e negritude. \\
\hline & $\begin{array}{l}\text { Histórias de pessoas negras (celebridades e comuns) como exemplo de superação da } \\
\text { inferioridade negra. }\end{array}$ \\
\hline
\end{tabular}

A mestiçagem no Brasil.

Racismo na mídia e em outros espaços sociais. 


\begin{tabular}{|c|c|}
\hline \multirow{2}{*}{$\begin{array}{l}\text { Democracia racial, } \\
\text { racismo e ações } \\
\text { afirmativas }\end{array}$} & $\begin{array}{l}\text { Preconceito e discriminação de forma geral. } \\
\text { Situações conflitantes sobre diversidade. } \\
\text { Discriminação racial na escola e possibilidades de solucionar o problema. }\end{array}$ \\
\hline & $\begin{array}{l}\text { Cotas e ações afirmativas. } \\
\text { Políticas de reconhecimento e de reparação. }\end{array}$ \\
\hline \multirow{7}{*}{$\begin{array}{l}\text { África e africanidades no } \\
\text { Brasil }\end{array}$} & África como berço da humanidade. \\
\hline & Países africanos: nome, localização e território etc. \\
\hline & $\begin{array}{l}\text { Valores civilizatórios africanos: oralidade, comunidade, circularidade, respeito aos mais } \\
\text { velhos etc. }\end{array}$ \\
\hline & $\begin{array}{l}\text { Especificidades culturais de países africanos } \\
\text { - A boneca AKUABA (Gana). } \\
\text { - O povo Ndebele (África do Sul). } \\
\text { - Máscaras africanas. }\end{array}$ \\
\hline & $\begin{array}{l}\text { Relação África-Brasil } \\
\text { Africanidades: turbantes, artesanato (fuxico), música e dança negra etc. }\end{array}$ \\
\hline & $\begin{array}{l}\text { Literatura afro-brasileira } \\
\text { - Contos africanos e afro-brasileiros. } \\
\text { - Mitos africanos e afro-brasileiros. } \\
\end{array}$ \\
\hline & $\begin{array}{l}\text { Religiões de matriz africana } \\
\text { - Desconstrução do preconceito contra religiões de matriz africana. } \\
\text { - Intolerância religiosa. } \\
\text { - Respeito às diversas religiões. }\end{array}$ \\
\hline
\end{tabular}

Fonte: elaboração própria.

O conjunto dos temas revela a ampliação do olhar para a cultura negra, até bem pouco tempo tratada apenas como religião, culinária e manifestação artística. Indica que existe um distanciamento da folclorização do mundo do povo negro, mostrando a possibilidade de enxergar mais que música, dança, comida e religião. Revela também a necessidade constante de formação sobre a História da África, uma história ainda pouco conhecida e uma história que ainda é subtraída dos currículos escolares. Em vários momentos, percebemos que existe uma tendência a aproximar o mundo africano do contexto brasileiro, como indicam as Diretrizes Curriculares Nacionais. Todavia nem sempre os temas são tratados a partir de uma perspectiva livre de estereótipos.

No caso da Escola Africanidades, não é rara a coexistência de tratamentos superficiais e tratamentos mais alinhados a uma perspectiva fundamentada, que evidencia a afirmação da população negra. Nessa escola, o discurso da mestiçagem ainda se faz presente de forma acentuada em seu cotidiano, o que, certamente, está relacionado com a visão que a cidade de Campinas construiu e possui sobre a população negra. No bloco de conteúdos relativos à supremacia branca e resistência negra, a leitura do livro "A história dos Escravos" "ganha destaque para aprofundar essa discussão. A situação didática aconteceu numa turma de $1^{\circ}$ ano, como preparação das crianças para a mostra anual. Vejamos a situação vivenciada:

A professora iniciou a leitura, rememorando com as crianças o trabalho que havia feito de localizar no mapa onde fica a África e o Brasil, retomando a primeira parte do livro que havia lido no dia anterior. O livro era "A Histórias dos Escravos" de Isabel Lustosa. A leitura foi realizada em tom

\footnotetext{
${ }^{6} \mathrm{O}$ livro conta a história dos escravos a partir de duas perspectivas: a de um avô que foi senhor de engenho e dono de escravos e de um avô que foi um negro liberto. Traz muitas informações preconceituosas sobre a vida no campo; a ideia da harmonia racial também está bastante marcada.
} 
de contação de história e sempre que aparecia uma palavra nova, a professora destacava, explicava ou perguntava quem sabia o significado dela. Também explorou algumas imagens, inclusive a imagem de uma escrava que segurava um bebê que não era negro, para explicar que "o povo brasileiro ficou todo misturadinho!"

Ao perguntar o que era senzala uma das crianças respondeu:

- É uma cidade no meio da selva.

A professora corrigiu:

- Não! Isso é um quilombo. Senzala era o lugar onde os escravos moravam na fazenda.

(Situação em sala de aula registrada no diário de campo em 30/10/20 |4).

A mentalidade da cidade, que ainda vê a população negra como o preto escravo, aliada à falta de uma formação sistemática, impossibilita maiores cuidados tanto na escolha dos materiais a serem utilizados como na forma de tratar o tema. E, desse modo, a situação didática termina por reproduzir a única história que aprendemos sobre a população negra no Brasil: a história da sua escravidão. O perigo de uma única história é discutido por Chimamanda Adichie ${ }^{7}$ que afirma que cada história pode ser composta por várias versões. Lembra a escritora: "comece uma história com as flechas dos nativos americanos, e não com a chegada dos britânicos, e você tem uma história totalmente diferente". No caso brasileiro, a resistência à escravidão é o contraponto da única história sobre a população negra no Brasil e pode ser abordada a partir de várias nuances.

No bloco identidade negra, autoestima e autoconceito, o tema igualdade e diferença ganha revelo porque é um assunto recorrente nas mais diversas situações e trabalhado a partir de variados contextos e concepções. Na Escola Africanidades, durante o ano de 20।4, um mote para a discussão foi a Copa do Mundo, que aconteceu no Brasil. A imagem abaixo traz um cartaz produzido pelos estudantes do $4^{\circ}$ ano com fotografias de jogadores de futebol de várias seleções. A mensagem é direta: todos os jogadores são igualmente jogadores de futebol, mas cada um deles joga em uma seleção diferente, que representa um país diferente, que possui povos diferentes, o que os torna diferentes. Logo, todos são, a um só tempo, iguais e diferentes.

7 Em conferência na TED Global 2009, disponível em: https://www.ted.com/talks/chimamanda_adichie_ the_danger_of_a_single_story?language =pt-br. Acesso em: 20 mar. 2013. 


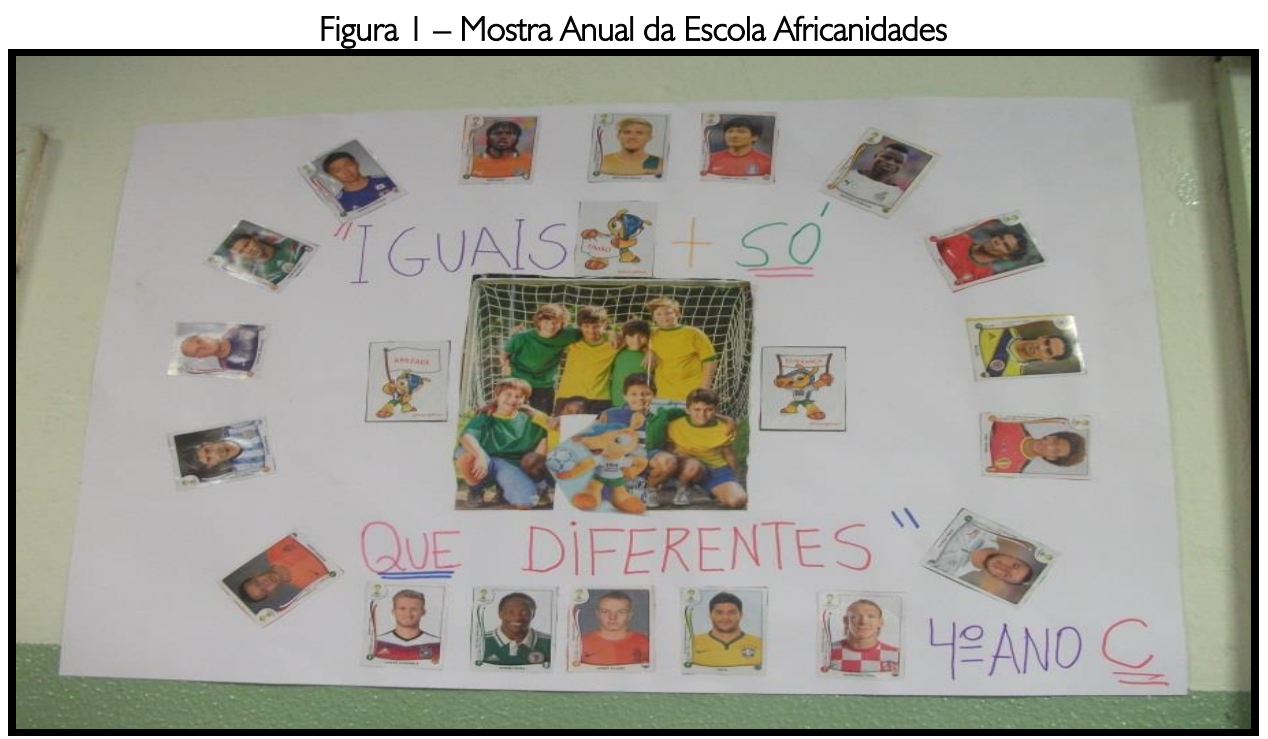

Foto: Claudilene Silva, 2014

Com as crianças menores o tratamento do tema soa como uma tranquilização psicológica. A tensão entre identidade/igualdade é uma vivência comum no processo de construção identitária de qualquer pessoa. Entretanto, no caso das crianças negras, o branqueamento, como ataque psicológico ao sentido de ser humano do negro, conforme indica Nobles (2009), atua na negação do direito à diferença, introjetando um conjunto de aspectos depreciativos ligados à pessoa negra, aos seus valores, às suas crenças, à sua relação com o trabalho, entre outras coisas, que as impedem de construir referências que Ihes deem suporte para valorizar sua origem africana, num contexto de supervalorização da brancura.

A mensagem da imagem que segue, uma produção de crianças do $1^{\circ}$ ano da Escola Baobá, é objetiva nesse sentido: todas e todos somos diferentes e isso não é um problema.

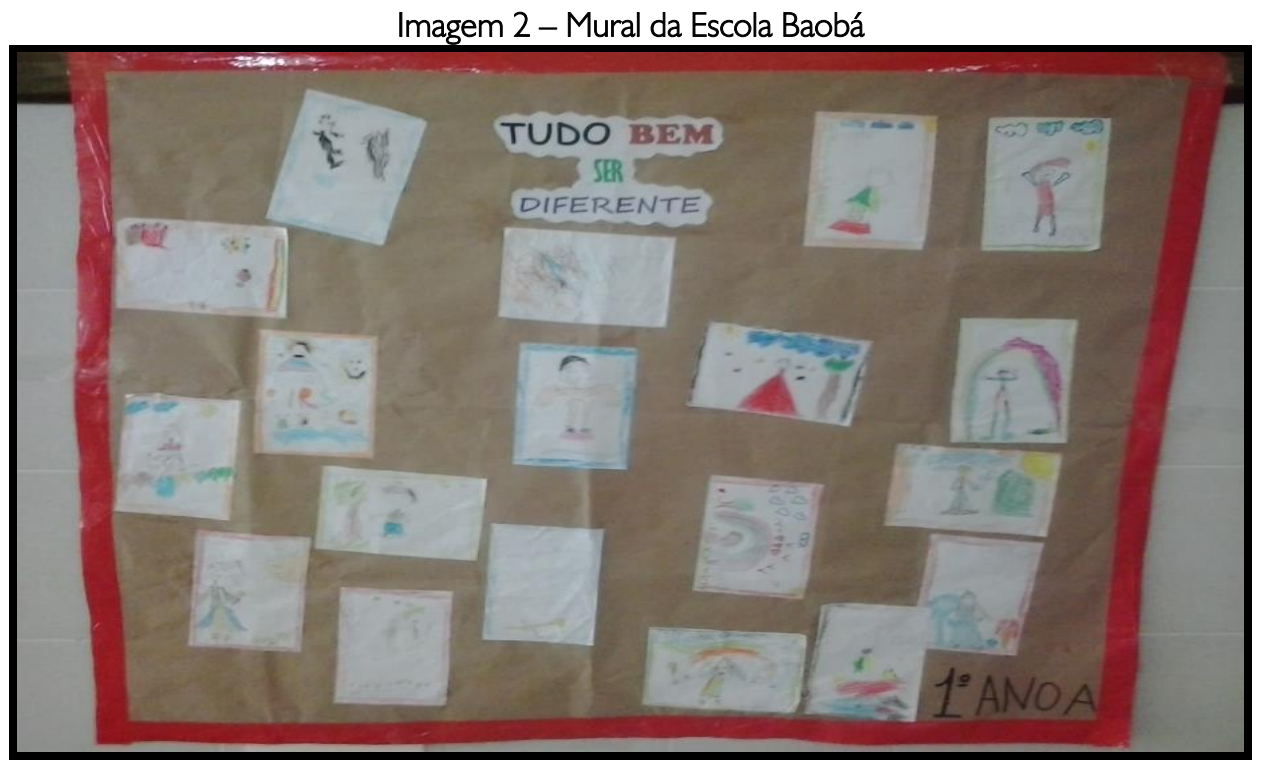

Foto: Claudilene Silva, 2015. 
O bloco temático sobre democracia racial, racismo e ações afirmativas é aquele no qual os mecanismos e as situações de discriminação étnico-racial se destacam. São questões que permeiam o ciclo de construção e vivência das práticas pedagógicas discutidas e aprofundadas ao longo de todo o trabalho.

No bloco temático África e africanidades no Brasil, as religiões de matriz africana ganham centralidade apresentando-se como principal ponto de tensão no desenvolvimento do trabalho sobre história e cultura afro-brasileira e africana. Por serem consideradas como práticas religiosas inferiores, essas religiões foram, sistematicamente, apresentadas à população brasileira como práticas demoníacas, associadas à bruxaria e à loucura, causando medo naqueles que não a conhecem (SILVA, 20 I 3). Municiada pelo medo e sem muita reflexão sobre o assunto, uma parte dessa população passou a reproduzir e disseminar o preconceito e a discriminação contra essas práticas religiosas até os dias de hoje. Frequentemente, é comum ouvirmos referências a termos como macumba, catimbó, xangô, entre outros que são vinculados à população negra, no sentido de desqualificar essa população e suas formas de conexão com o divino.

Os termos são utilizados como formas genéricas e pejorativas de se referir às religiões de matriz africana e a depreciação dessas práticas religiosas é fundamentada pela sua classificação como "coisa de nego", que, nesse caso, possui a conotação de "coisa do mal”. De acordo com Martha Queiroz ( 1999 ), essas religiões são perseguidas e inferiorizadas exatamente em função de sua ascendência negra. É o racismo que opera na perseguição e na depreciação dessas religiões. Dada a ligação histórica de algumas das manifestações artísticas afro-brasileiras surgirem nas casas religiosas de matriz africana ou em função delas, é comum ouvirmos referências sobre expressões artísticas do povo negro como "coisas do mal" ou "coisas do diabo". Algumas das manifestações culturais artísticas afro-brasileiras possuem fundamentação religiosa, mas não são religião.

medo das "coisas de nego" foi construído, de diversas formas, na sociedade brasileira, e ainda está impregnado na mente e no olhar da população brasileira, impedindo-a de enxergar tanto a manifestação cultural religiosa como a manifestação cultural artística da população negra por lentes que não as inferiorizem e nem as discriminem como coisas do demônio. Por esses motivos, múltiplos são os casos de preconceito religioso que acontecem no espaço escolar, resultando da ação voluntária ou involuntária dos docentes, gestores, funcionários diversos e também dos estudantes e seus familiares, especialmente, entre as famílias evangélicas. Contudo, para ensinar história e cultura afro-brasileira e africana, os profissionais da educação não precisam se aproximar das religiões de matriz africana como sistema religioso, embora não possam ignorá-las como manifestação cultural dos povos negros, uma vez que são elementos de resistência e afirmação da identidade cultural desses povos (SILVA, 20 I3).

Na Escola Baobá, o tema ganha concretude por meio da escuta e utilização dos mitos afrobrasileiros e africanos para trabalhar os conteúdos disciplinares. Todavia, sempre que se faz necessário, a 
discussão da intolerância religiosa é realizada de forma direta, permeando toda a organização da dinâmica escolar.

Na primeira unidade de 2015, durante a exibição do filme "Besouro Cordão de Ouro", produção cinematográfica que conta a história do lendário capoeirista Manoel Henrique Pereira e sua relação com o universo religioso afro-brasileiro, as professoras responsáveis pela atividade identificaram manifestações preconceituosas direcionadas a uma estudante do $5^{\circ}$ ano, adepta do Candomblé. Ao ser informada sobre o que ocorreu, a equipe gestora propôs, na reunião coletiva de planejamento do $2^{\circ}$ bimestre, cujo foco seriam os modos de vida africano e indígena, que $05^{\circ}$ ano trabalhasse "o árido tema do combate à intolerância religiosa durante toda a unidade ${ }^{8 " .}$. Assim, a coordenação pedagógica sugeriu atividades, materiais, filmes etc. para a abordagem do assunto.

As professoras do $5^{\circ}$ ano planejaram suas atividades buscando tratar articuladamente os conteúdos disciplinares e o tema proposto para a unidade. Um dos materiais utilizados para introduzir o assunto foi o livro "Minhas Contas" de autoria de Luiz Antônio, que narra a história de Pedro e Nei, dois amigos inseparáveis proibidos pela mãe de Pedro de brincar juntos por causa dos fios de $\operatorname{contas}^{9}$ que Nei usa. Tanto o texto quanto as ilustrações apresentam as características de alguns orixás e discutem o Candomblé como culto à natureza até o desfecho da situação conflituosa que havia se instalado. O livro foi utilizado no momento costumeiro da leitura e realizou-se a interpretação do texto.

Naquela mesma semana de introdução do tema combate à intolerância religiosa, aconteceria a avaliação do Prosa, e, para essa atividade, o conteúdo disciplinar de língua portuguesa trabalhado foi o gênero textual notícia. Esse conteúdo também foi discutido por meio do tema combate à intolerância religiosa por meio da notícia de uma garota que foi apedrejada ao sair de um culto de Candomblé. Encarado como "árido", conforme já descrito, o tema da unidade também foi pautado na reunião de pais das turmas do $5^{\circ}$ ano, disponibilizando às famílias o assunto que as crianças estavam trabalhando em sala de aula e explicando a perspectiva que levou a essa discussão. Entre as famílias que estavam presentes na reunião, não houve reação contrária à discussão do tema.

Tanto para as famílias quanto para as crianças, o tema foi introduzido e trabalhado de forma gradual. A professora informou que trabalhariam intolerância, afirmou que a ideia era trabalhar a questão do respeito e do conhecimento e só depois pontuou que também trabalharia intolerância religiosa. Entretanto expressou com firmeza a necessidade de construirmos relações respeitosas para com as diversas religiões. Em ambos os casos, a professora explicou que a escola não trabalha religião, trabalha o respeito a todas as religiões e o conhecimento sobre as religiões de matriz africana para que saibamos respeitá-las. A

\footnotetext{
${ }^{8}$ Coordenador pedagógico em reunião de planejamento registrada em 19/06/20। 5.

${ }^{9}$ Colares coloridos utilizados pelos adeptos das religiões de matriz africana após o ritual de iniciação como objetos de identificação que unem os fiéis aos deuses que os protegem. Também conhecidos como guias.
} 
imagem abaixo ilustra a forma como o conhecimento sobre o mundo africano aparece na escola relacionada à vida e à cosmovisão dos povos africanos e não a uma religião.

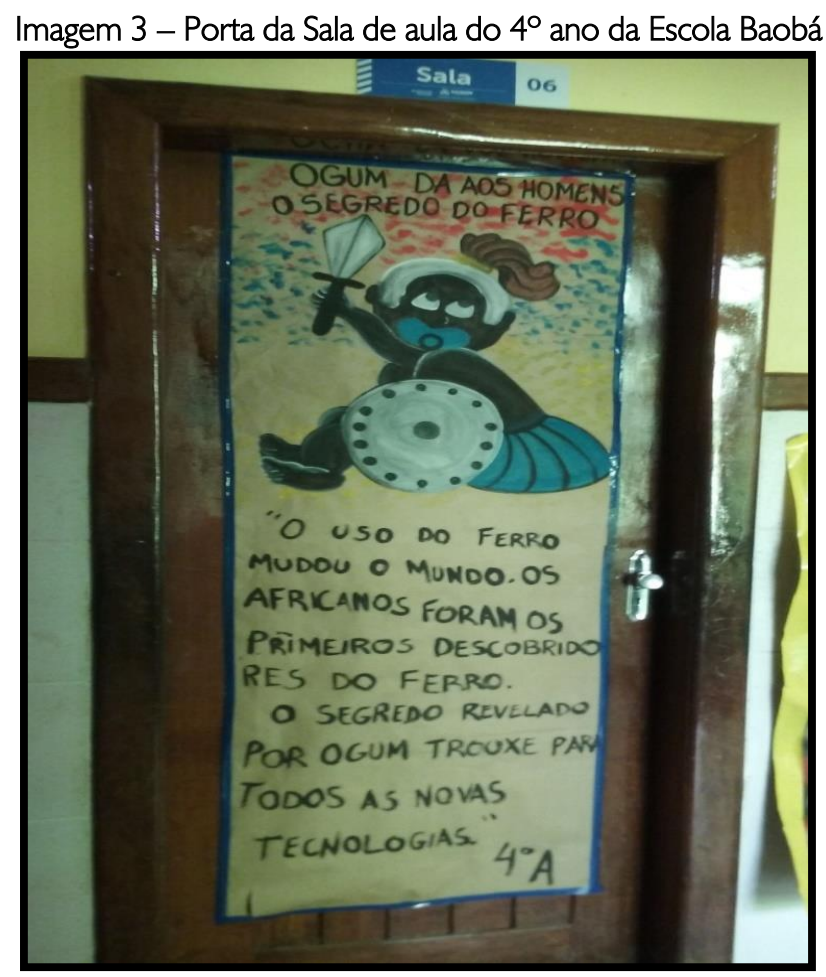

Foto: Claudilene Silva, 2015.

Compreendemos que as religiões de matriz africana são a base da cultura afro-brasileira. Foi por meio do culto às suas divindades que os africanos que aqui chegaram, na condição de escravizados, organizaram-se culturalmente. Entretanto reduzir o ensino de história e cultura afro-brasileira à discussão das religiões de matriz africana trata-se de um equívoco gerado por uma visão racista, preconceituosa e estereotipada da história da população negra. Assim, concordamos com Gomes (20 I 2) quando afirma que a implementação da política curricular aponta um lugar mais denso para a educação escolar: a dimensão do conhecimento. Para a autora, "reconhecer os saberes, as crenças, a arte, a literatura, a poesia, os valores, a história, as lutas da população afro-brasileira e africana, além de ser uma iniciativa de combate ao racismo, configura-se também como uma postura política e epistemológica" (GOMES, 20 I 2b, p. 349).

\subsection{Situações didáticas vivenciadas em história e cultura afro-brasileira e africana}

No que se refere às situações didáticas que corporificam as práticas pedagógicas, consideramo-las como a globalidade da ação por meio da qual os sujeitos envolvidos no processo de ensino e de aprendizagem se relacionam na construção do conhecimento. Em outros termos, as relações-se dão entre os sujeitos em ação, em um contexto movido por materiais e um conjunto de atividades. Assim, 
consideramos que são essas situações que dão corpo às práticas pedagógicas enraizadas de valorização da identidade, da memória e da cultura negras: aquelas que possuem uma finalidade entendida, explicada e argumentada pelos sujeitos da escola, cujas características são a repetição crítica, a continuidade e a consistência. Desse modo, na análise das situações didáticas vivenciadas pelas escolas, buscamos evidenciar as atividades que as contextualizam, o conteúdo dos materiais utilizados e as relações dos sujeitos com o saber em processo de construção.

As atividades são diversificadas adequando-se a cada ano ou segmento de ensino: leitura de mapas; confecção de cartazes e artefatos culturais; pesquisa da literatura ou da oralidade; vivências e apresentações culturais; exibição de filmes e conversas cotidianas; essas são algumas das ações desenvolvidas. No entanto, em seu conjunto, a leitura e a contação de histórias, a exposição dialogada, a produção escrita e as tarefas disciplinares ganham relevo, aparecendo com maior frequência e articulando conteúdos disciplinares e conteúdos educativos referentes à temática. A utilização dos mitos e dos contos africanos e afro-brasileiros é recorrente para abordar conteúdos variados como podemos notar no quadro a seguir:

Quadro 2 - Situações didáticas que valorizam a história e cultura afro-brasileira e africana

\begin{tabular}{|c|c|c|}
\hline ATIVIDADE & CONTEÚDOS & RELAÇÕES \\
\hline $\begin{array}{c}\text { Leitura, } \\
\text { Contação e } \\
\text { interpretação de } \\
\text { Histórias }\end{array}$ & $\begin{array}{l}\text { Livros infantis } \\
\text { - Menina bonita do laço de fita } \\
\text { - Bruna e a galinha d'angola } \\
\text { - Minhas contas } \\
\text { - Minha mãe é negra sim! } \\
\text { Mitos africanos e afro-brasileiros } \\
\text { - lansã e a democracia } \\
\text { - Ossain O protetor das folhas } \\
\text { - Oxum e seu mistério } \\
\text { Contos africanos e afro-brasileiros } \\
\text { - A árvore de cabeça para baixo } \\
\text { - Amigos, mas não para sempre } \\
\text { - A árvore que prendeu a mulher do entalhador } \\
\text { Pessoas Negras } \\
\text { - Personalidades e comuns }\end{array}$ & $\begin{array}{l}\text { Momentos de escuta } \\
\text { Momentos de leitura } \\
\text { Reflexão dialógica }\end{array}$ \\
\hline Exposição dialogada & $\begin{array}{l}\text { Reflexão sobre o contexto } \\
\text { - Situação da população negra } \\
\text { - Conjuntura política da cidade } \\
\text { - Reparação e ações afirmativas }\end{array}$ & $\begin{array}{l}\text { Momentos de escuta } \\
\text { Reflexão dialógica }\end{array}$ \\
\hline Produção escrita & $\begin{array}{l}\text { História da Bahia } \\
\text { Cultura africana e afro-brasileira } \\
\text { História de personalidades negras } \\
\text { Acontecimentos cotidianos } \\
\text { Releitura dos livros, mitos e contos. }\end{array}$ & $\begin{array}{l}\text { Momentos de escuta } \\
\text { Reflexão dialógica } \\
\text { Reflexão individual } \\
\text { Construção individual ou } \\
\text { coletiva do texto }\end{array}$ \\
\hline $\begin{array}{c}\text { Tarefas e avaliações } \\
\text { disciplinares }\end{array}$ & $\begin{array}{l}\text { Conteúdos disciplinares } \\
\text { Conteúdos educativos/temáticos }\end{array}$ & $\begin{array}{c}\text { Reflexão individual } \\
\text { Construção individual ou } \\
\text { coletiva das respostas }\end{array}$ \\
\hline Leitura de mapas & Localização da África e do Brasil & Reflexão dialógica \\
\hline
\end{tabular}




\begin{tabular}{|c|c|c|}
\hline $\begin{array}{l}\text { Confecção de } \\
\text { cartazes e artefatos } \\
\text { culturais }\end{array}$ & $\begin{array}{l}\text { Penteados afros } \\
\text { Releitura dos livros infantis, mitos e contos africanos e } \\
\text { afro-brasileiros } \\
\text { Diversidade cultural, racismo e discriminação racial } \\
\text { Artefatos culturais de países africanos }\end{array}$ & $\begin{array}{l}\text { Momentos de escuta } \\
\text { Reflexão dialógica } \\
\text { Reflexão individual } \\
\text { Construção individual ou } \\
\text { coletiva do material }\end{array}$ \\
\hline $\begin{array}{l}\text { Pesquisa em livros, } \\
\text { material publicitário, } \\
\text { com pessoas mais } \\
\text { velhas comunidade }\end{array}$ & $\begin{array}{l}\text { Cultura africana e afro-brasileira } \\
\text { Situação da população negra } \\
\text { Representação do negro na mídia } \\
\text { História da comunidade }\end{array}$ & $\begin{array}{l}\text { Leitura de textos diversos } \\
\text { Momentos de escuta } \\
\text { Reflexão dialógica } \\
\text { Construção individual ou } \\
\text { coletiva das respostas }\end{array}$ \\
\hline $\begin{array}{l}\text { Vivências e } \\
\text { apresentações } \\
\text { culturais }\end{array}$ & Capoeira, Hip Hop, Samba, Maracatu & $\begin{array}{l}\text { Momentos de escuta } \\
\text { Experimentação corporal } \\
\text { Expressão corporal }\end{array}$ \\
\hline Exibição de filmes & $\begin{array}{l}\text { Kiriku e a feiticeira } \\
\text { Besouro Cordão de Ouro } \\
\text { Ranhia Nzinga }\end{array}$ & $\begin{array}{l}\text { Momentos de } \\
\text { escuta/visualização } \\
\text { Reflexão dialógica }\end{array}$ \\
\hline $\begin{array}{c}\text { Conversas } \\
\text { espontâneas }\end{array}$ & $\begin{array}{l}\text { Autoestima e orgulho do pertencimento } \\
\text { Situação da população negra } \\
\text { Histórias de pessoas personalidades negras }\end{array}$ & Reflexão dialógica \\
\hline
\end{tabular}

Fonte: elaboração própria.

O uso pedagógico dos mitos põe em evidência outras possibilidades de aprendizagem, apontando para dois campos: conceitual e prático. Cumpre uma primeira função de aproximação com o pensamento africano, com os modos de compreensão do mundo e da vida das populações africanas. Por outro lado, como afirma Vanda Machado (20 I5) e de acordo com o pensamento de Paulo Freire, quando a situação problematizadora é contextualizada a criança compreende melhor. E o mito "estrutura, revela e exibe algo que é capaz de enfeixar todo um conjunto de valores" (MACHADO, 20 I 5, p. 07), oferecendo um sentido lógico, que cria as condições para a aprendizagem significativa. Nesse sentido, consideramos que a utilização pedagógica dos mitos africanos recriados no Brasil indica um avanço na perspectiva de partimos das experiências dos povos ancestrais para fundarmos um pensamento "outro", como propõe (WALSH, 2007).

A ação pedagógica é quase sempre realizada a partir de conteúdos disciplinares e as disciplinas nas quais a temática mais aparece são: História, Língua Portuguesa, Ciências, Matemática, Geografia, Artes e o Atendimento na Educação Especial. Todavia é recorrente a existência de um trabalho interdisciplinar quando o conteúdo permite. Por meio da variedade de materiais utilizados, tais como livros, contos, mitos, filmes, dança, música, mapas, textos, cartazes, tarefas e avaliações, a história e cultura afro-brasileira e africana são apropriadas como conteúdos de ensino e de aprendizagem. Ao que parece, a diversificação de atividades e materiais presentes no trato pedagógico da temática indica que essa é uma questão que não tem como ser trabalhada uniformemente. Para envolver as estudantes e os estudantes, é apresentada de diferentes formas e a partir de diferentes suportes, que the possibilitam estar sempre presente na dinâmica escolar (SILVA, 2009). 
A continuidade da temática no cotidiano da instituição escolar possibilita o aprofundamento da discussão e o monitoramento do conhecimento que está sendo construído. A intervenção do professor oferece desafios ao pensamento das estudantes e dos estudantes, que, na maioria das vezes, são resolvidos coletivamente, como foi possível notar na oficina temática mídia e racismo, realizada na Escola Africanidades, já narrada e analisada nessa sessão. Dessa forma, as situações didáticas são iniciadas com momentos de leitura, de escuta, de visualização ou de experimentação corporal, por meio dos quais as professoras e professores buscam aproximar as estudantes e os estudantes do conteúdo e do tema a serem trabalhados.

Nas aulas da Professora Luanda ${ }^{10}$, que acompanhamos na Escola Baobá, a interação com as estudantes e os estudantes acontece quase sempre a partir do conhecimento que já possuem ou de algo próximo às suas realidades, sem limitar-se a elas. A docente disponibiliza o caminho que será percorrido informando o objetivo e a intenção de cada passo e, sempre que possível, possibilita que as estudantes e os estudantes participem das decisões necessárias. A nota a seguir, tenta captar esse processo. Vejamos:

A professora inicia a conversa explicando que naquela semana trabalhariam em geografia "noção de espaço: país, estado, cidade". E que a aula do dia seria sobre a ideia de cidade. E indaga ao grupo: - $\bigcirc$ que temos numa cidade? As crianças, muito inquietas, não responderam. A professora continuou: - Existem espaços que são muito importantes para uma cidade: escolas, hospitais, posto médico, moradias etc. Alguém pergunta: - Como se mede o tamanho de uma cidade? As crianças ficam em silêncio. A professora responde: - Existem questões territoriais que limitam os espaços. As primeiras cidades foram construídas perto dos rios. Porque será? Uma menina responde: - Para a utilização da água? Isso mesmo, responde a professora. Em seguida entrega um texto para as crianças " A favela como espaço da cidade" e após a leitura do título pergunta: porque vocês acham que surgiram as favelas? As crianças ficam em silêncio. Um garoto responde: - Porque quando os negros foram libertos, não tinham para onde ir. Os brancos, os portugueses os expulsaram da cidade e os negros precisavam de algum lugar para onde ir, porque se ficassem perambulando na cidade, eles eram presos, por causa da Lei da Vadiagem. Então os negros e os pobres invadiram os lugares que ainda não estavam ocupados. As crianças ainda estavam bem dispersas. Para envolver o grupo a professora pediu que um estudante fizesse a pergunta para que um outro respondesse. Aos poucos, mas com a intervenção permanente da professora, o debate foi crescendo (Situação e sala de aula registrada no diário de campo em 17/07/20 I 5).

Como é possível perceber, a oralidade como um princípio da cosmovisão africana, orienta as práticas. "No pensamento africano, a fala ganha força, forma e sentido, significado e orientação para a vida. A palavra é vida, é ação, é jeito de aprender e de ensinar" (MACHADO, 20I5, p. 08). E a relação básica que constitui as situações didáticas é a reflexão dialógica. É pelo diálogo e pela reflexão crítica da realidade, como propõe Paulo Freire (20I I), que o conhecimento é construído individual e coletivamente, dando corpo às práticas enraizadas e transformando-as em rituais pedagógicos.

\footnotetext{
10 Nome fictício.
} 


\section{CONSIDERAÇÕES FINAIS}

As diferentes dinâmicas e experiências das escolas que compuseram o campo empírico da pesquisa apresentam aproximações no que se refere às formas de vivenciar as relações interconectadas que constituem o todo da prática pedagógica escolar e alguns distanciamentos na forma de organizar o tempo curricular destinado aos conteúdos pedagógicos em história e cultura afro-brasileira e africana. A investigação evidenciou que cada unidade escolar engendra o ciclo de construção e vivência das práticas pedagógicas relacionadas à temática de acordo com suas realidades, seus contextos e suas condições materiais de trabalho.

O percurso de organização e a experiência das escolas nos permitem afirmar que as práticas pedagógicas de valorização da história e cultura afro-brasileira e africana são construídas e vivenciadas numa relação de disputa curricular, que explica porque a perspectiva epistêmica do trabalho nem sempre apresenta distanciamentos significativos das práticas eurocêntricas que produziram a subalternização da população negra no Brasil.

A disputa curricular vivenciada na escola é também uma disputa política e social. A produção acadêmica do campo curricular tem chamado atenção a esse respeito há algum tempo. No espaço da escola, o grau de intensidade das vivências das práticas depende das visões política e social e da disposição do grupo que está ganhando a disputa no momento. Assim, aprofundar essas relações de disputa e compreender o contexto de construção e vivência das práticas pedagógicas de valorização da história e da cultura afro-brasileira e africana ganham relevância no processo de construção dos novos rituais pedagógicos.

Todavia, no que se refere ao emprego do tempo curricular, os achados revelam que as diferentes formas de abordagem dos conteúdos, os temas que constituem as práticas e as situações didáticas que a ela dão corpo tomam por referência princípios da cosmovisão africana recriada no Brasil em diálogo com o pensamento de Paulo Freire e geram uma forma outra de pensar e fazer educação.

Desse modo, é possível afirmar que os diferentes desafios enfrentados pelas duas escolas na construção, na vivência e no enraizamento de suas práticas pedagógicas de valorização da história e cultura afro-brasileira e africana oferecem contribuições que nos ajudam a visualizar passos no processo de descolonização e de reinvenção da escola e da educação no Brasil. 


\section{REFERÊNCIAS}

ASANTE, Molefi Kete. Afrocentricidade: notas sobre uma aposição disciplinar. In: NASCIMENTO, Elisa Larkin (Org.). Afrocentricidade: uma abordagem epistemológica inovadora. São Paulo: Selo Negro, 2009.

BARDIN, Laurence. Análise de conteúdo. Tradução: Luís Antero Reto e Augusto de France. 4. ed. Lisboa: Edições 70, 2011.

BRASIL. Lei $n^{\circ} 10.639$ de 9 de janeiro de 2003. Altera a Lei n 9.394, de 20 de dezembro de 1996, que estabelece as diretrizes e bases da educação nacional. Brasília, 2003.

BRASIL. Diretrizes Curriculares Nacionais para a Educação das Relações Étnico-Raciais e para o Ensino de História e Cultura Afro-Brasileira e Africana. Brasília, 2004.

CUNHA JR, Henrique. Afrodescendência e africanidades: um dentre os diversos enfoques possíveis sobre população negra no brasil. Revista Interfaces de Saberes. Caruaru v. I, n 13, p. I - 13, 2013.

CURY, Carlos Roberto Jamil. Educação e Contradição: elementos metodológicos para uma teoria crítica do fenômeno educativo. São Paulo: Cortez, 1992.

FREIRE, Paulo. Pedagogia da Autonomia: saberes necessários à prática educativa. São Paulo: Paz e Terra, 2010.

FREIRE, Paulo. Educação como prática da liberdade. São Paulo: Paz e Terra, 201 I.

GATTI, Bernadete; BARRETO, Elba; ANDRÉ, Marli. Políticas Docentes no Brasil: um estado da arte. Brasilia: UNESCO, 20II.

GOMES, Nilma Lino. Limites e Possibilidades da Implementação da Lei 10.639/03 no Contexto das Políticas Públicas em Educação. In: PAULA, Marlene; HERINGER, Rosana (Orgs.). Caminhos

Convergentes: Estado e Sociedade na superação das desigualdades raciais no Brasil. Rio de Janeiro: Fundação Heinrich Boll, ActionAid, 2009.

GOMES, Nilma Lino. Alguns termos e conceitos presentes no debate sobre relações raciais no Brasil: uma breve discussão, 201 2a. Disponível em: http://www.acaoeducativa.org.br/fdh/wpcontent/uploads/2012/I0/Alguns-termos-e-conceitos-presentes-no-debate-sobre-

Rela\%C3\%A7\%C3\%B5es-Raciais-no-Brasil-uma-breve-discuss\%C3\%A3o.pdf

GOMES, Nilma Lino. (Org.). Práticas Pedagógicas de Trabalho com Relações Étnico-Raciais na Escola na Perspectiva da Lei 10.639/03. Brasília: MEC; UNESCO, 20 I 2b.

GONÇALVES E SILVA, Petronilha Beatriz. Lei no 10.639/2003 - 10 ANOS. Revista Interfaces de

Saberes, Caruaru, v. I, n 13, p. I-13, 2013.

GONÇALVES, Luís Alberto. O silêncio: um ritual pedagógico a favor da discriminação. 1985.

Dissertação (Mestrado em Educação) - Faculdade de Educação, Universidade Federal de Minas Gerais, Belo Horizonte, 1985.

GUIMARÃES, Antonio Sérgio Alfredo. Racismo e Anti-Racismo no Brasil. Rio de Janeiro, Ed. 34, 1999. 
MACHADO, Vanda. Mitos afro-brasileiros e vivências educacionais. 20 I5. Disponível em: http://educacao.salvador.ba.gov.br/wordpress/wp-content/uploads/20 I 5/05/mitos.pdf?9879 I b. Acesso em: 10 set. 2015.

MUNANGA, Kabengele. Uma Abordagem Conceitual das Noções de Raça, Racismo, Identidade e Etnia. Cadernos PENESB-5. Programa de Educação Sobre o Negro na Sociedade Brasileira - Niterói, EdUFF, 2000.

NOBLES, W. Wade. Sakhu Sheti: retomando e reapropriando em foco psicológico afrocentrado. In: NASCIMENTO, Elisa Larkin (Org.). Afrocentricidade: uma abordagem epistemológica inovadora. São Paulo: Selo Negro, 2009.

OLIVEIRA, Luiz Fernandes. Histórias da África e dos Africanos na escola: tensões políticas, epistemológicas e indenitárias na formação docente. Anais do XXVI Simpósio Nacional de História ANPUH, p. I- I8, São Paulo, julho 201।.

OLIVEIRA, Eduardo. Filosofia da ancestralidade como filosofia africana: Educação e cultura afro-brasileira.

Revista Sul-Americana de Filosofia e Educação. Brasília, n. I8, p. 28-47, maio-out/20। 2, 2012.

OLIVEIRA, Luiz Fernandes. A Etnografia Ajuda a Entender as Relações Raciais na Escola? 2013.

Disponível em: http://www.maxwell.lambda.ele.puc-

rio.br/rev_edu_online.php?strSecao=show I I \&fas=5 I. Acesso em: I 5 maio 20 I3.

QUEIROZ, Martha Rosa Figueira de. Religiões afro-brasileiras no Recife: policiais, intelectuais e repressão. 1999. Dissertação (Mestrado em História) - Centro de Filosofia e Ciências Humanas, Universidade Federal de Pernambuco, Recife, 1999.

QUIJANO, Aníbal. Colonialidade do poder, Eurocentrismo e América Latina. In: LANDER, Edgardo (org.). A colonialidade do saber: eurocentrismo e ciências sociais: perspectivas latino-americanas. CLACSO, Buenos Aires: Argentina, 2005 (Colección Sur Sur).

SANTIGO, Maria Eliete. Escola Pública de Primeiro Grau: da compreensão à intervenção. Rio de Janeiro: Paz e Terra, 1990.

SANTIGO, Maria Eliete. Formação, Currículo e Prática Pedagógica em Paulo Freire. In: BATISTA NETO, José; SANTIAGO, Eliete (Orgs.). Formação de Professores e Prática Pedagógica. Recife: Fundação Joaquim Nabuco, Ed. Massangana, 2006.

SILVA, Claudilene. O Processo de Implementação da Lei n $10.639 / 03$ na Rede Municipal de Ensino do Recife. In: AGUIAR, Márcia Ângela da S. et al. (Org.). Educação e Diversidade: estudos e pesquisas. Recife: Gráfica J. Luiz Vasconcelos Ed., 2009.

SILVA, Claudilene. Professoras Negras: identidades e práticas de enfrentamento do racismo no espaço escolar. Recife: Ed. Universitária da UFPE, 2013 (Coleção Etnicorracial).

SILVA, Maria do Socorro. As Práticas Pedagógicas das Escolas do Campo: a escola na vida e a vida como escola. 2009. Tese (Doutorado em Educação) - Centro de Educação, Universidade Federal de Pernambuco, Recife, 2009.

SANTOS, Gislene Aparecida de. A Invenção do "Ser Negro": um percurso das idéias que naturalizaram a inferioridade dos negros. São Paulo: Educ/Fapesp; Rio de Janeiro: Pallas, 2002. 
SOUZA, João Francisco. Prática Pedagógica e Formação de Professores. In: BATISTA NETO, José; SANTIAGO, Maria Eliete (Orgs.). Formação de Professores e Prática Pedagógica. Recife: Ed. Universitária da UFPE, 2009.

WALSH, Catherine. Interculturalidad, colonialidade y educación. Revista Educación y Pedagogia, Medellín, Universidade de Antioquia, Facultad de Educación, vol. XIX, núm. 48, p. 25 - 35, Mayoagosto, 2007. 